\title{
CONCEPTUAL AUTONOMY AND SEMANTIC IDENTITY IN EU LAW: BALANCING ON THE EDGE OF PRESCRIPTION AND EXTINGUISHMENT OF A RIGHT
}

\author{
Doc. JUDr. Marianna Novotná, Ph.D.* \\ Mgr. Jozef Štefanko, Ph.D., LL.M.**
}

\author{
UDK: 341.176:341.24(4)EU \\ 34.82.03(4EU) \\ 340.113:341.176(4)EU \\ DOI: 10.3935/zpfz.71.6.02 \\ Izvorni znanstveni rad \\ Primljeno: prosinac 2021.
}

By examining the nature of the time limit for the right to compensation for damage caused by defective products (Article 11 of Directive 85/374/EEC - Product Liability Directive) in relation to the Slovak legal order (Act no. 294/1999 Coll. on Liability for defective products implementing the EU Directive), the authors address the question of the consequences of the conflict between the different language versions of the Directive. At the same time, they examine whether the semantic identity of the different linguistic expressions and the conceptual autonomy of a term of EU law do not allow for different legal consequences in different implementation environments.

Keywords: semantic identity, multilingualism of EU law, product liability, prescription, extinguishment of a right

* Doc. JUDr. Marianna Novotná, Ph.D., Associate Professor, Faculty of Law, Trnava University, Kollárova 545/10, 91701 Trnava, Slovakia; marianna.novotna@gmail.com; ORCID ID: orcid.org/0000-0001-7725-0102)

** Mgr. Jozef Štefanko, Ph.D., LL.M., Assistant Professor, Faculty of Law, Trnava University, Kollárova 545/10, 91701 Trnava, Slovakia; stefanko@stefanko.sk;

ORCID ID: orcid.org/0000-0003-1168-9598 


\section{INTRODUCTION ${ }^{1}$}

The European Union as an organization and a phenomenon is undoubtedly a mixture of many identities (state, national, ethnic, social, cultural, etc.) that are reflected every day in its institutions and in national political and social activities, which affect the substance and functioning of the EU. Its legislation is a product of the effort to blend in - or to use the very prominent notion to harmonize - the law into a unified and autonomous whole ${ }^{2}$ and, at the same time, it is the product of individual, differently conditioned, approaches of the actors concerned. Is it possible to transform this diversity into a unitary whole? The philosophical idea of conceptual schemes ${ }^{3}$ that filter human perceptions, data, and the overall mutual communication of people in their relationships suggests that a complete understanding of others' perceptions is an unattainable venture, and the absolute clarity and predictability of relationships is intrinsically excluded. The way people try to overcome the indicated problem and identify a "common background" that would be consistently understandable and sufficiently general for various situations is their submission to normative systems. And the existing gaps in this general framework are being complemented by other mutually shared features ${ }^{4}$ forming the framework, where an individual communicates his or her ideas in society. Whether we call them "social norm" (Durkheim), "social practice" (Wittgenstein), a general social understanding labelled "habitus" (Bourdieu) or communication "charity"5 (Davidson), the very first and fundamental mechanism to overcome mutual misunderstanding, to

1 Research for this paper was made possible as a part of the project no. APVV-170562 .

2 Here we mean the reconciliation of diverse approaches and understandings in the creation of autonomous EU law as a new legal order, not the harmonization of national law. See also Craig, P.; De Búrca, G., EU LAW: Text, Cases, and Materials, $5^{\text {th }}$ ed., Oxford University Press, Oxford, 2011, pp. 88 and 256.

3 It is the idea of organizing experiences, "a system [one or more systems] of categories that take the form of a summation of perceptions; they are special views according to which individuals, cultures or epochs process the scenery in front of them." See the discussion on conceptual schemes in Davidson, D., On the Very Idea of a Conceptual Scheme, in: Davidson, D., Inquiries into Truth and Interpretation, Clarendon Press, Oxford, 1984, p. 185.

4 Taylor, Ch., To Follow a Rule, in: Calhoun, C.; Lipuma, E.; Postone, M. (eds.), Bourdieu: Critical Perspectives, University of Chicago Press, Chicago, 1993, pp. 46-59.

5 Davidson, D., op. cit. (fn. 3), pp. 196-198. Davidson's charity means a way of actively sharing a mutually understandable language based on agreement - a premise that the other party understands something. 
which all other elements follow, is the language. Naturally, in the EU, where this basic common element is absent and replaced by 24 official and many other regional and minority languages, the integrity and unambiguous mutual understanding of its law is all the more difficult, since the very result of the pursuit for an autonomous content (the norms of EU law) is not expressed by a single language, but by several, all with a formally equivalent status. Moreover, within EU private law discourse, it is noteworthy to point out the bitter conclusion of a number of authors dealing with EU law and its private-law implications: researchers of the private law acquis often lack a broader view, a perspective reaching beyond the technical rationality of many provisions, or at least beyond the national impact of some EU regulation. ${ }^{6}$ Thus, even in the application of private law in specific matters as they are manifested in the national law, it is not enough simply to read the text expressed in one of the official languages, but the methods normally used by legal comparativism should also be employed so that the multi-level nature of EU law can be fully accounted for within private law relations too. Basedow e.g. calls for a broader understanding of the sources (formants) of EU private law, which should be reflected in the interpretation of its provisions. It should take into account (1) the text of a specific directive or regulation in different official languages; (2) the motives for adopting an act, from which conclusions can be drawn in relation to the meaning of the European norm as such and of its individual provisions; (3) the legal basis that expresses a similar value, while defining the limits of its use; (4) the case-law of the judicial authorities on the interpretation of the act in question; (5) implementing laws from other Member States that will help to understand this legal act, through the understanding and experience of the foreign legislator with the act; (6) foreign literature and case law on the implementing measures of a foreign Member State. ${ }^{7}$ It is difficult to imagine that such a complex legal-application and legal-interpretation activity would be carried out by every addressee of EU law, but as we present in this article, the divergence of expressions of a certain norm in various languages may lead to a completely contradictory conceptual understanding of a particular legal institution and thus to different legal consequences in different Member States, which is contrary to the fundamental value of harmonization acts - achieving unity of legal consequences.

6 See e.g. Basedow, J., Nationale Justiz und Europäisches Privatrecht : eine Vernetzungsaufgabe, C. F. Müller, Heidelberg, 2003, p. 22; similarly Hesselink, M. W., The Common Frame of Reference as a Source of European Private Law, Tulane Law Review, vol. 83, no. 4, 2009 , p. 944.

7 For the enumeration see Basedow, J., op. cit. (fn. 6), p. 32 and generally the whole publication. 
For the sake of completeness, it is necessary to mention that the plurality of languages of legal acts is also an issue within the regime of international law, which - as Křepelka argues - is not inherently multilingual, but is a mixture of generally accepted principles, widely accepted usages and multilateral, plurilateral and bilateral conventions. It is not necessary to anchor such law in a number of languages simultaneously. ${ }^{8}$ Bilateral international treaties are negotiated in the languages of the contracting parties, whereas in the case of multilateral international conventions, they are negotiated in the selected languages (language), which then become the authentic languages. Conventions drawn up in these authentic languages are of the same status and solely these language versions are considered to be a binding text of the convention in question. Other translations of multilateral conventions into the languages of the states that are parties to these conventions cannot be considered binding versions of the convention and as such are of no relevance from the perspective of international law. From the point of view of international practice, such translations are insignificant because if there is a mismatch between the official wording and the translation into a language that is not an authentic language of the convention, the official wording of the international convention would always prevail as decisive in the application process. While there may be a conflict between the language versions of these conventions, even in relation to the authentic versions of international conventions, the European Union's position is specific in this context. Above all, linguistic diversity is an integral part of European identity respected as a fundamental value of the EU. The multilingual nature of the EU results from regulation No. 1, dating from 1958, determining the languages to be used by the former European Economic Community ${ }^{9}$, which has been amended in respect to subsequent accessions to the EU. According to this regulation, together with Art. 55 (I) TEU, legislation and policy documents of significant public importance (documents of general application) shall be made available in all 24 of the official languages ${ }^{10}$ of the EU. Documents, which an EU institution sends to a member state or to a person subject to the jurisdiction of a member state, shall be drafted in the language

8 Křepelka, F., Mnohojazyčný režim práva Evropské unie a jeho di̊sledky pro českou právní praxi, in: Hurdík, J.; Fiala, J.; Selucká, M. (eds.), Evropský kontext vývoje českého práva po roce 2004, Masarykova univerzita, Brno, 2006, p. 30.

9 OJ 17, 6.10.1958, p. 385.

10 The official EU languages since 1958 have been Dutch, French, German, Italian; since 1973 Danish and English; since 1981 Greek; since 1986 Portuguese and Spanish; since 1995 Finnish and Swedish; since 2004 Czech, Estonian, Hungarian, Latvian, Lithuanian, Maltese, Polish, Slovak, Slovenian; since 2007 Bulgarian, Irish, Romanian and since 2013 Croatian. 
of such state. Other documents, including correspondence, are translated on an as needs basis, and any internal documents are written in a working (also procedural) language in accordance with a specific language policy implemented by the respective EU institution pursuant to art. 6 of the regulation 58/1/EEC, usually English, French and German. The EU legal order is construed on the principle of multilingualism.

A concrete example of the situation of conflicting different language versions of a directive as a source of EU law can be illustrated by the Directive 85/374/ EEC on the approximation of the laws, regulations and administrative provisions of the Member States concerning liability for defective products ${ }^{11}$ in its provisions governing a time limit for asserting the right to compensation for damage caused by a defective product. Based on the analysis of the provisions in question, which reflects the aforementioned complexity of the actual meaning of the relevant provision of EU law, in relation to the Slovak legal order, we examine the consequences of the inconsistency and look for a purported semantic identity in these manifestly different versions for the purposes of their autonomous and uniform application.

\section{DEFINITION OF THE PROBLEM AND ROOTS OF THE PRESENT STATE OF AFFAIRS}

Binding legislative acts adopted at Union level are intended either to be directly applied in national legal systems of the member states or to be implemented in national legal systems. When it comes to directives, which pursuant to Article 288 of the Treaty on the functioning of the European Union (TFEU) are required to be transposed into national law, this means that, at the national level, the transposition of the directive usually leads to the creation of new national legislation aimed at achieving the results pursued by Union legislation. At this point, a terminological clash may occur between a Union legislative text (bearing a multi-cultural and multi-lingual context) and a national legislative text (that carries the elements of adapting Union text to the national legal context). However, in some cases, the conflict between Union law and national law may have its roots already in the process of translation.

The Slovak version of the Directive 85/374/EEC as well as Section 9 para. 2 of Act no. 294/1999 Coll. defines the ten-year limitation period as a prescription period without the consequence of extinguishment of the respective right. All other language versions of the directive examined (only those were chosen by

11 OJ L 210, 7.8.1985, pp. 29-33. 
the authors that could be linguistically responsibly assessed by them, i.e. English, German, French, Czech, Polish and Dutch ${ }^{12}$ provide for an unambiguous extinction of the right to damages of the injured party as a legal consequence of the expiry of the period of ten years from the date on which the producer put the product into circulation (except where the injured party initiated a court proceedings during that ten years, i.e. he or she sued for damages).

Art. 11 of the Directive, which enshrines extinguishment of the right to damages as a legal consequence of the expiry of the ten-year period in the language versions examined, follows Art. 10 (regulating a three-year prescription period of a subjective nature) and supplements it. In the process of drafting the Directive this two-step limitation system of prescription and extinguishment was taken from the US product liability law. Common law as such does not recognize prescription periods in the continental sense. In the US law (as well as

12 English version: "Member States shall provide in their legislation that the rights conferred upon the injured person pursuant to this Directive shall be extinguished upon the expiry of a period of 10 years from the date on which the producer put into circulation the actual product which caused the damage, unless the injured person has in the meantime instituted proceedings against the producer."

Czech version: "Členské státy ve svých právních předpisech stanoví, že práva udělená poškozené osobě na základě této směrnice zanikají uplynutím deseti let ode dne, kdy výrobce uvedl do oběhu daný výrobek, který způsobil škodu, pokud poškozená osoba mezitím nedala podnět k zahájení řízení proti výrobci."

German version: "Die Mitgliedstaaten sehen in ihren Rechtsvorschriften vor, daß die dem Geschädigten aus dieser Richtlinie erwachsenden Ansprüche nach Ablauf einer Frist von zehn Jahren ab dem Zeitpunkt erlöschen, zu dem der Hersteller das Produkt, welches den Schaden verursacht hat, in den Verkehr gebracht hat, es sei denn, der Geschädigte hat in der Zwischenzeit ein gerichtliches Verfahren gegen den Hersteller eingeleitet."

French version: "Les États membres prévoient dans leur législation que les droits conférés à la victime en application de la présente directive s'éteignent à l'expiration d'un délai de dix ans à compter de la date à laquelle le producteur a mis en circulation le produit, même qui a causé le dommage, à moins que durant cette période la victime n'ait engagé une procédure judiciaire contre celui-ci."

Polish version: "Państwa Członkowskie zagwarantują w swoim ustawodawstwie, że prawa przyznane osobie poszkodowanej zgodnie z przepisami niniejszej dyrektywy, wygasają po upływie okresu 10 lat od daty wprowadzenia przez producenta do obrotu produktu, który spowodował szkodę, chyba że osoba poszkodowana wszczęła przed upływem tego terminu postępowanie przeciwko producentowi."

Dutch version: "De Lid-Staten bepalen in hun wetgeving dat de rechten die de gelaedeerde aan deze richtlijn ontleent, komen te vervallen na een termijn van tien jaar, te rekenen vanaf de dag waarop de producent het produkt dat de schade heeft veroorzaakt in het verkeer heeft gebracht, tenzij de gelaedeerde gedurende die periode een gerechtelijke procedure tegen hem heeft ingesteld." 
in the English law), such limitation periods are introduced by provisions of the respective state law. In the United States, a distinction is made between statutes of limitation ( $c f$. continental prescription) and statutes of repose (cf. continental extinguishment of rights). ${ }^{13}$ Relatively short statutory limitation periods (from two to four years) have been supplemented through a US Supreme Court decision by a so-called discovery rule, i.e. by a rule, under which these periods begin to run only if the subject concerned has learnt of his or her personal injury. In this way, the duration of rights and claims has been very significantly prolonged in many areas. The legislature addressed this phenomenon in the 1970s by introducing limitation periods of 10-12 years leading to extinguishment of rights (statutes of repose) for ever more areas (medicine, architecture, product liability). Thus, the limitation (extinguishment) period in this context should be a counterweight to the subjective prescription period, the beginning of which is tied to the subjective moment of obtaining (or presumed acquiring) knowledge of the defect, of the damage and of the responsible subject, which can be a very long period of time, in particular in the event of latent health damage. ${ }^{14}$

\section{CONTRADICTION BETWEEN THE LANGUAGE VERSIONS OF A DIRECTIVE AND ITS SOLUTION}

Every reasonable theory of interpretation of legislation attaches importance to words and to their meaning. The interpretation of a norm starts with the semantics, but it never gives it the last word in legal interpretation. ${ }^{15}$ Specifically focussing on EU law in terms of semantics two basic elements of its nature have

13 See Reimann, M., Liability for defective products at the beginning of the twenty-first century: Emergence of a worldwide standard?, American Journal of Comparative Law, vol. 51, no. 4, 2003, p. 779.

14 In Germany, the nature and length of the limitation (extinguishment) period is primarily justified as a means of balancing the presumption of the original defectiveness of the product at the time of its placement on the market under Paragraph 1 of the German Produkthaftungsgesetz, as well as a means of preventing failure of evidence as a result of passing of a too long period (BTDrs 11/2447, 25). This justification would not stand in the Slovak legal order, as the Slovak Act No. 294/1999 Coll. does not set forth the presumption of defectiveness of a product (on the contrary, in its Section 1 it introduces the obligation of the injured party to prove the defect of a product) and the argument of preventing failure of evidence would just as much apply to the limitation (extinguishment) as to the prescription of rights.

15 Moore, M. S., Semantics, Metaphysics, and Objectivity in the Laws, in: Keil, G.; Poscher, R., (eds.), Vagueness and Law: Philosophical and Legal Perspectives, Oxford University Press, Oxford, 2016, p. 129. 
been put forward, namely its conceptual autonomy and its multilingualism. ${ }^{16}$ With regard to the former, it should be noted that legal terms are always a semantic expression of a legal concept. A concept can be considered autonomous in a transnational sense, if it activates its own group of elements of knowledge at the transnational (European) level and not at the national level of the Member States. ${ }^{17}$ By interpreting concepts at this transnational level, autonomous Union meaning is attributed to the relevant concept, and consequently Union law can be applied in a consistent way, irrespective of the divergence of Member States' laws. EU law is largely fragmented in content, so coherent "elements of knowledge" cannot be taken solely from one source level (the transnational one). Even autonomous Union concepts must then be quite specific, targeted. In concrete cases, their binding conceptualisation is mainly carried out by the Court of Justice of the EU (hereinafter "CJ EU") in its legal-interpretation activities $^{18}$, but it is a general feature of the interpretation process. The second characteristic trait of EU law, which is particularly necessary to be accounted for in the present analysis, is its multilingualism and at the same time the equally binding force of all official language versions of the sources of EU law. It is not just a doctrinal principle, but a binding rule ${ }^{19}$, which has also been repeatedly reaffirmed by the CJ EU. ${ }^{20}$ However, it went even further by explaining that it is not possible to rely on one official language version only when interpreting EU law rule, but on the contrary that "interpretation of a provision of [EU] law [...] involves a comparison of the different language versions" and "even where the different language versions are entirely in accord with one another, [...] legal concepts do not necessarily have the same meaning in [EU] law and in the law of the various member states", and lastly that "every provision of [EU] law must

16 Bajčić, M., New Insights into the Semantics of Legal Concepts and the Legal Dictionary, John Benjamins Publishing Company, Amsterdam / Philadelphia, 2017, p. 79 et seq.

17 Ibid., p. 80.

18 In this way in specific cases the CJ EU is seeking autonomous meaning of various concepts for the purposes of autonomous interpretation of the relevant source of EU law, e.g. "compensation for use" (Case 489/07 Pia Messner v. Stefan Krüger [2007] I-7315), "personal injury" (Case C 22/12 Katarína Haasová v Rastislav Petrík and Blanka Holingová) and many others.

19 In particular, the Council Regulation 1/1958/EEC on the use of languages in the European Economic Community, as amended. As Bajčić points out, the rule is based on post-war international law, namely the Vienna Convention on Contract Law of 1969. See Bajčić, M., op. cit. (fn. 16), p. 92 et seq.

20 See e.g. Case C-361/01 P Christina Kik v. Office for Harmonization in the Internal Market [2003] ECR I-8283; Case C-283/81 Srl CILFIT and Lanificio di Gavardo SpA v Ministry of Health [1982] ECR 3415. 
be placed in its context and interpreted in the light of the provisions of [EU] law as a whole, regard being had to the objectives thereof and to its state of evolution at the date on which the provision in question is to be applied". ${ }^{21}$ As a result of all these considerations, if there is any doubt about the meaning of an EU law term, which is contained in the source thereof, there is no authentic text that could be simply resorted to in order to solve the problem by itself. ${ }^{22}$

Building on the situation of equality of languages on one hand and the desireable semantic identity of all language versions of EU legislation on the other hand, however, since in this case there is a contradiction between one and many language versions of the text of the Directive, it is necessary to arrive at the true meaning of Art. 11 of the Directive through interpretation (and consequently the Slovak wording of the Directive needs to be interpreted accordingly). Despite the equality of all language versions of the Directive, the Slovak version and its wording of Article 11 cannot be considered binding in isolation and interpreted without taking into account other language versions thereof. On the contrary (although without an explicit support in the legislative text) the case law of the CJ EU implies the obligation to interpret Union law in the light of all its official language versions. ${ }^{23}$ Preference for a single language version of the Directive to the detriment (without taking into account) of others could lead to a violation of the principle of equality.

Since in this context the exclusive literal interpretation of the Slovak wording cannot lead to a solution of the issue in question, the meaning and purpose of the provision must be determined by the use of a logical, systematic or teleological interpretation by examining the broader context and purpose of the legislation. ${ }^{24}$ Even the legitimate expectations ${ }^{25}$ of the Slovak addressees (in this case exemplified by deeming the limitation period as a period for prescription) cannot be regarded as the most relevant criterion, as the CJ EU has concluded that conflicting language versions should be interpreted in favor of individuals

21 These rules have been introduced by the reasoning of CJ EU in CILFIT (C-283/81, 18-20).

22 In this sense Bajčić. See Bajčić, M., op. cit. (fn. 16), p. 94.

${ }^{23}$ Cf. cases of the CJEU 29/69 Stauder v. Ulm [1969] ECR 419, C-219/ P Ferriere Nord SpA v. Commission [1997] ECR I-4411.

${ }^{24}$ See case C-80/76 North Kerry Milk Products Ltd. v. Minister for Agriculture [1977] ECR 425.

25 See Mészáros, P., The principle of the legitimate expectations, Pravo i suspil'stvo, vol. 6, 2017, pp. 91-99. 
only if it does not conflict with the objective of the legislation. ${ }^{26}$ Thus, it can be concluded that, in the event of one version being different from other language versions caused by incorrect translation, the text needs to be interpreted and applied in the light of the text as explicated in the other official languages ${ }^{27}$, i.e. it is necessary to give priority to an interpretation which, in addition to being consistent with the purpose of the rule, ensures the most effective and complete achievement of that purpose.

\section{PRESCRIPTION, EXTINGUISHMENT AND PRACTICAL CONSEQUENCES OF DIFFERENT REGULATION}

Unlike some other directives adopted in the 1980s and 1990s, which included a clause on the degree of their harmonization, mostly electing minimal harmonization $^{28}$, Directive 85/374 does not directly state to what extent Member States are at liberty to reach beyond its wording while transposing the directive (of course without violating the transposition goal). Retrospectively, and at a time when the approach of maximum and later targeted full harmonization ${ }^{29}$ has started to gain prominence within EU legislation, and especially in the EU private law directives, the Court of Justice of the EU held that Directive 85/374 should also be deemed a tool for maximum harmonization. ${ }^{30}$ However, this should not be understood to be leading to absolute uniformity of laws, but only as a harmonization focused on selected issues determined by the objectives of the Directive, whose different implementation would be destructive to the internal market. ${ }^{31}$ For example, in Henning Veedfald v. Arhus Amtskommune ${ }^{32}$ the

26 See case C-1/02 Privat-Molkerei Borgmann GmbH \& Co. KG v. Hauptzollamt Dortmund [2004] ECR I-3219.

27 See case C-63/06 UAB Profisa v. v Muitines departamentas prie Lietuvos Respublikos finansu ministerijos [2007] ECR I-3239.

28 See Jančo, M., in: Jančo, M.; Jurčová, M.; Novotná, M. et al., Európske súkromné parvo, Euroiuris, Bratislava, 2012, p. 30.

29 See ibid., pp. 29-32.

30 Commission v. France, case C-52/00 [2002] ECR I-3827. See also Verheyen, T., Full Harmonization, Consumer Protection and Products Liability: A Fresh Reading of the Case Law of the ECJ, European Review of Private Law, vol. 26, no. 1, 2018, pp. 119-140.

31 White, F., Directive 85/374/EEC concerning liability for defective products: in the name of harmonisation, the internal market and consumer protection, in: Giliker, P. (ed.), Research Handbook on EU Tort Law, Edward Elgar Publishing, Cheltenham, Northampton, 2017, pp. 136-137.

32 Case C-203/99, [2001] ECR I-3569. 
Court of Justice, while interpreting this Directive, has admitted that the precise content of a term not defined in the Directive may be given to it by the Member States, provided that the objectives of the Directive are properly fulfilled. ${ }^{33}$ Although the problem we are analyzing starts with a deficiency present already at the level of unfolding the meaning of Union law (its conflicting translation of a black-letter rule), at the end of the day the difference will ultimately only be manifested through the application of national law that implements the relevant wording and only then can any potential conflict with autonomous EU law and with the goals of the relevant Directive be consummately pronounced.

Whether the conflict of the wording of the law and of the Directive interpreted in the light of the other language versions and the consequent assumption of the incorrect Slovak translation into the national legislation leads to anchoring stricter than the Union regulation, can only be based on the comparison of the individual attributes associated with the institution of extinguishment of rights on the one hand and prescription on the other. The basic starting point is that the Directive refers in Art. 11 to the extinguishment of the right to damages upon the expiry of the ten-year period, whereas the Slovak act imposes a prescription period, which results in no extinction of the right, but only in the expiry of the justiciable claim (i.e. the expiry of the court claim). From this point of view it is an example of so-called goldplating ${ }^{34}$, since through the institution of prescription a greater obligation is being imposed on the subject concerned, in comparison to the Directive, in order to achieve a result similar to the one anticipated by the Directive (i.e. achievement of a denial of the aggrieved party's claim for

33 In this case, the issue was the interpretation of the basic terms "damage resulting from death or personal injury" and its distinction from "property damage", whereas the court's interpretative condition was that full compensation of the injured parties should be granted in any event. See White, F., op. cit. (fn. 31), p. 150.

34 It is a well-established indication of the practice where transposition of EU legislation goes beyond what is required by this legislation while remaining within the limits of legality. Within the scope of the Member State's ability to adopt different implementing measures, this practice may include eg. more extensive administrative obligations, procedural conditions or stricter sanction mechanisms. If it is not about illegality, gold-plating is usually considered a bad practice. See Boci, M.; De Vet, J. M.; Pauer, A., 'Gold-plating' in the EAFRD: To what extent do national rules unnecessarily add to complexity and, as a result, increase the risk of errors? (IP/D/AL/FWC/209-056 ed.), Directorate-General for Internal Policies of the Union, Brussels, 2014, p. 27. Available at: http://www.europarl.europa.eu/RegData/etudes/etudes/join/2014/490684/ IPOL-JOIN_ET(2014)490684_EN.pdf (18 January 2022); see also Kral, R., On the Choice of Methods of Transposition of EU Directives, European Law Review, vol. 41, no. 2, 2016, pp. 220-242 (introducing goldplating as a recognised method of transposition of a directive). 
compensation by the court). It is namely the obligation to take an active action in the court in the form of the need to assert the objection of prescription. On the other hand, in the case of expiry of the period for extinguishment of the right to damages, it takes full effect solely by operation of law (ex lege) and the court is obliged to take it into account on its official duty without the need for the defendant (the tortfeasor) to actively raise any objection. Goldplating is also at stake as to the legal consequence pertaining to the possibility to perform after the elapse of the ten years period. In the case of the foreseen interpretation of the Directive, the injured party (consumer) cannot receive damages from the liable entity, since such performance would constitute an unjust enrichment on the part of the injured party. In contrast, Slovak national legislation allows the injured party to obtain compensation even after the ten-year period has elapsed. This would result if the responsible entity (the producer) did not exercise the objection of prescription in the court proceedings, notwithstanding it was a mere mistake or voluntary omission. They would also be able to perform voluntarily outside of the context of litigation. In such cases, the payments would not amount to unjust enrichment on the part of the injured party.

True, the Directive, in relation to the temporal limitation of the right to compensation for damage caused by a defective product in this context, introduces extinguishment of the right to damages in an objective ten-year period as a clear legal consequence. Nevertheless, the nationally governing period of limitation embedded in the statutory provision does not create a significant obstacle to the business environment in Slovakia and as such it cannot be truly seen as an obstacle to the realization of freedoms in the internal market. This follows due to the fact that even in the case of prescription, a similar legal effect would be achieved in relation to the right of the injured party to claim damages, as in the case of limitation period for extinguishment of the right. Although with prescription the subjective right does not extinguish as a result of the limitation period, the court would just as much not recognize the claim, should the defendant assert the objection of prescription. The unconditional actionablility of the right to damages has indeed extinguished and the court would not oblige the responsible entity to compensate the damage. As a result, the responsible entity is protected to more or less the same extent, since in the case of extinguishment of the right to damages the responsible subject ends up without the obligation to provide compensation for the damage inflicted. On the contrary, the limitation period in a form of prescription undoubtedly has advantages in relation to both the injured party as well as to the producer as the responsible entity. If the manufacturer voluntarily chooses to compensate for the damage - even after elapse of the ten-year period - he may do so and the injured party would not be considered unjustly enriched as in the case of 
the former concept; it will not be necessary to painstakingly develop complex justifications for making the payment (e.g. through a relationship of donation). The manufacturer himself may be interested in compensating the injured party even ten years after the defective product has been placed on the market, either as a matter of building his commercial goodwill, as a matter of exercising a more pro-consumer approach within his corporate policy, etc. The only real difference in the application of the concept at issue in the national regime would surface if the producer as a defendant in a lawsuit does not assert prescription of the claim in court while and at the same time denying and arguing against the injured party's claim - an eventuality of rather academic nature. ${ }^{35}$

For the sake of comparison, we would like to point out that the Czech legislature even proceeded to change the nature of the limitation period in question from originally conceptualizing it as a condition for extinguishment of the right to the prescription thereof under the current legislation. Pursuant to the previous Czech regulation in Section 9 of Act no. 59/1998 Coll. on product liability the right to damages would be prescribed in a subjective period of three years from the time when the injured party learned or could reasonably be expected to have known about the damage, defect of the product and the identity of the producer, taking into account all the circumstances. This was supplemented by an objectively assessed prescription period of ten years from placing the product on the market. By a subsequent amendment of this Act ${ }^{36}$ a new Section 9a replaced the said objective prescription period and - following the wording of the Directive within the endeavor to prepare the Czech legal order for the entry into force of the Treaty on Accession of the Czech Republic to the EU - provided for the extinction of the right to compensation for damages upon the expiration of the period of ten years otherwise fashioned in the same way. With the entry into force of the new Czech Civil Code (Act no. 89/2012 Coll. Civil Code) the legal regulation of product liability in a separate act was abolished and the legislation on this issue was (with some changes) transferred to the Civil Code and is now found in Section 2939 et seq. One of those changes was indeed the change of the nature of the objectively assessed period from extinguishment to prescription. The justification therefor rested, in particular, in the possibility

35 If, in such a case, the Slovak court deciding on such a case wanted - very strictly to take into account the "extinction" of the right under Art. 11 of the Directive, it would be able to do so by means of the Euroconform interpretation. That is without the need for a consummate dismantling of the nationally anchored principle of voluntary-compensation-is-not-precluded that the concept of prescription naturally entails.

See Act no. 209/2000 Coll. amending the Act no. 59/1998 Coll. on product liability. 
for the producer to voluntarily grant compensation to the injured party even after that ten-year period.

\section{CONCLUSION}

Nelson Mandela said that "language is the highest manifestation of social unity in the history of mankind, and it is the inherent right of each group of people to use its language without restriction." ${ }^{37}$ Multilingualism in the EU and its law is undoubtedly one of the most important values that is particularly worthy of protection and of cultivation as a manifestation of respect for the diversity of Member States' national identities. At the same time, however, it is also an onerous burden for a proper, uniform, and especially predictable interpretation of the notions used in EU law. The introduction of autonomous Union concepts in the jurisdiction of the CJ EU is referred to as the legal-interpretative "Columbus egg" because it eliminates the burden of comparing and translating between languages and cultures. It can also be seen as a basis for building a genuine common European law and a European legal language. ${ }^{38}$ The semantic identity, which in EU law replaces the linguistic identity (i.e. the unattainable identity of various language versions if translated into a single target language by traditional methods of translation) of the various language versions of the official texts of the relevant legal act, is tied to the conceptual level, not to the purely terminological one. Our contextual analysis of different language versions of Article 11 Directive no. 85/374/EEC plastically illustrates the possible deviations in the conceptual anchorage of the 'extinguishment' of the right to compensation for damage caused by a defective product, whether through the institute of prescription or of extinguishment of the right. It is true that both the Slovak text and the transposition instrument (along with the current Czech transposition instrument) deviate at first sight from the 'European' concept, but we are of the opinion that the autonomous European concept expressed in Article 11 of the Directive cannot be drawn from the very institutions of prescription or extinguishment of right in their entirety, which have genuinely different legal consequences if they are embedded in a particular national legal system. Rather we need to stop one level higher, where it does not matter whether the right as such extinguishes or it is only its enforceability that expires. Since in both cases the objectives pursued by the Directive are adequately protected on

37 Quoted by Masiola, R.; Tomei, R., Law, Language and Translation: From Concepts to Conflicts, Springer, Cham et al., 2015, p. vi.

38 Bajčić, M., op. cit. (fn. 16), p. 89. 
both sides of the creditor-debtor relationship. The Directive insists unequivocally on that that after the expiry of the respective period, the aggrieved party would not be able to successfully claim compensation and that the wrongdoer is guaranteed protection against any assertion of such a claim by the aggrieved party. This is achieved by the analyzed concept in each of the two interpretation schemes. Although we have found that the Slovak law in this matter might be "goldplating" the Union's regulation, it does not entail a material contradiction therewith nor a violation of the state's transposition obligation, since the interests of both parties are probably even better protected through the institution of prescription, taking into account any possible willingness of a liable party to voluntarily submit itself to mere 'obligatio naturalis ${ }^{39}$ as well as the interest in adherence to the principle that the professional should be vigilant in execution of the protection of their rights. Thus, also in our example, it can be established that the principle of conceptual autonomy of notions introduced by EU law necessarily implies what we call semantic identity of various language versions of the underlying EU law text. Clearly, it does not follow merely from the fact that all language versions are equally authentic and authoritative ${ }^{40}$, but rather from the need to have a notion to at least some degree have a uniform, autonomous, European meaning, even though the individual translations of the said norms into a single language (or into a single legal order for that matter) would bring about differing results, if it only were to rely on a single conceptual scheme of the target language. Ultimately, the ascertaining of a semantically identical concept must be based on a broad contextual interpretative basis leading to restrictive conclusions on the concept in question, which is limited strictly to the objectives pursued by the norm that introduced it. Since, in order to reach our findings, we had to undertake a conceptual analysis of the directive in question crossing the boundaries of national law, language and semantics, we believe we have also demonstrated how the contemporary practice of interpretation and application of law calls for an interdisciplinary approach and thus is becoming more demanding on, yet all the more interesting for, decent lawyering.

39 See Riedl, K., Natural Obligations in Comparative Perspective, Rabels Zeitschrift für ausländisches und internationales Privatrecht, vol. 85, no. 2, 2021, pp. 402-433 (explaining comprehensively the concept and arguing for its universal nature).

40 There are various interpretative methods used even by the CJ EU to overcome discrepancies between language versions of EU law norms, some of which might even attribute higher relevancy to only some of the versions (e.g. majority meaning). For a thorough analysis see Otero Fernández, I., Multilingualism and the Meaning of EU Law, European University Institute, Florence, 2020, p. 157 et seq. Available at: https:// cadmus.eui.eu/bitstream/handle/1814/66308/Fernandez_2020_LAW.pdf (18 January 2022). 


\section{BIBLIOGRAPHY}

Bajčić, M., New Insights into the Semantics of Legal Concepts and the Legal Dictionary, John Benjamins Publishing Company, Amsterdam / Philadelphia, 2017.

Basedow, J., Nationale Justiz und Europäisches Privatrecht: eine Vernetzungsaufgabe. C. F. Müller, Heidelberg, 2003.

Boci, M.; De Vet, J. M.; Pauer, A., 'Gold-plating' in the EAFRD: To what extent do national rules unnecessarily add to complexity and, as a result, increase the risk of errors? (IP/D/AL/FWC/209-056 ed.), Directorate-General for Internal Policies of the Union, Brussels, 2014, p. 27. Available at: http://www.europarl.europa. eu/RegData/etudes/etudes/join/2014/490684/IPOL-JOIN_ET(2014)490684_ EN.pdf (18 January 2022).

Craig, P.; De Búrca, G., EU LAW: Text, Cases, and Materials, $5^{\text {th }}$ ed., Oxford University Press, Oxford, 2011.

Davidson, D., On the Very Idea of a Conceptual Scheme, in: Davidson, D., Inquiries into Truth and Interpretation, Clarendon Press, Oxford, 1984, pp. 185-198.

Hesselink, M. W., The Common Frame of Reference as a Source of European Private Law, Tulane Law Review, vol. 83, no. 4, 2009, pp. 919-971.

Jančo, M.: Jurčová, M.; Novotná, M. et al, Európske súkromné právo, Euroiuris, Bratislava, 2012.

Kral, R., On the Choice of Methods of Transposition of EU Directives, European Law Review, vol. 41, no. 2, 2016, pp. 220-242.

Křepelka, F., Mnohojazyčný režim práva Evropské unie a jeho důsledky pro českou právní praxi, in: Hurdík, J.; Fiala, J.; Selucká, M. (eds.), Evropský kontext vývoje českého práva po roce 2004, Masarykova univerzita, Brno, 2006, pp. 29-45.

Masiola, R.; Tomei, R., Law, Language and Translation: From Concepts to Conflicts, Springer, Cham et. al., 2015.

Mészáros, P., The principle of the legitimate expectations, Pravo i suspil'stvo, vol. 6, 2017, pp. 91-99.

Moore, M. S., Semantics, Metaphysics, and Objectivity in the Laws, in: Keil, G.; Poscher, R. (eds.), Vagueness and Law: Philosophical and Legal Perspectives, Oxford University Press, Oxford, 2016, pp. 127-157.

Otero Fernández, I., Multilingualism and the Meaning of EU Law, European University Institute, Florence, 2020. Available at: https://cadmus.eui.eu/bitstream/ handle/1814/66308/Fernandez_2020_LAW.pdf (18 January 2022).

Reimann, M., Liability for defective products at the beginning of the twenty-first century: Emergence of a worldwide standard?, American Journal of Comparative Law, vol. 51, no. 4, 2003, pp. 751-838. 
Riedl, K., Natural Obligations in Comparative Perspective, Rabels Zeitschrift für ausländisches und internationales Privatrecht, vol. 85, no. 2, 2021, pp. 402-433.

Taylor, Ch., To Follow a Rule, in: Calhoun, C.; Lipuma, E.; Postone, M. (eds.), Bourdieu: Critical Perspectives, University of Chicago Press, Chicago, 1993, pp. 45-60.

Verheyen, T., Full Harmonization, Consumer Protection and Products Liability: A Fresh Reading of the Case Law of the ECJ, European Review of Private Law, vol. 26, no. 1, 2018, pp. 119-140.

White, F., Directive 85/374/EEC concerning liability for defective products: in the name of harmonisation, the internal market and consumer protection, in: Giliker, P. (ed.), Research Handbook on EU Tort Law, Edward Elgar Publishing, Cheltenham, Northampton, 2017, pp. 128-153. 
Sažetak

\section{Marianna Novotná" \\ Jozef Štefanko**}

\section{KONCEPTUALNA AUTONOMIJA I SEMANTIČKI IDENTITET U PRAVU EU-a: BALANSIRANJE NA RUBU IZMEĐU ZASTARE I PRESTANKA PRAVA}

Ispitujući pravnu prirodu rokova za ostvarenje prava na naknadu štete prouzročene neispravnim proizvodom prema čl. 11. Direktive Vijeća od 25. srpnja 1985. o približavanju zakona i drugih propisa država članica u vezi s odgovornošću za neispravne proizvode (85/374/EEC) u odnosu prema slovačkom pravu (Zakon br. 294/1999 o odgovornosti za neispravne proizvode kojim je Direktiva prenesena u nacionalno zakonodavstvo), autori u radu obrađuju pitanje posljedica razlika među različitim jezičnim verzijama Direktive. Istodobno se postavlja pitanje dopuštaju li semantički identitet različitih jezičnih izraza $i$ konceptualna autonomija pojmova unutar prava EU-a različite pravne posljedice u različitim implementacijskim okružjima.

Ključne riječi: semantički identitet, višejezičnost u pravu EU-a, odgovornost za neispravan proizvod, zastara, prestanak prava

* Dr. sc. Marianna Novotná, izvanredna profesorica Pravnog fakulteta Sveučilišta u Trnavi, Kollárova 545/10, 91701 Trnava, Slovačka; marianna.novotna@gmail.com; ORCID ID: orcid.org/0000-0001-7725-0102)

** Dr. sc. Jozef Štefanko, docent Pravnog fakulteta Sveučilišta u Trnavi, Kollárova 545/10, 91701 Trnava, Slovačka; stefanko@stefanko.sk;

ORCID ID: orcid.org/0000-0003-1168-9598 